\title{
Mechanisms for Correcting Judicial Errors in Germany
}

\author{
Michael Lindemann \& Fabienne Lienau*
}

\section{Abstract}

The article presents the status quo of the law of retrial in Germany and gives an overview of the law and practice of the latter in favour of the convicted and to the disadvantage of the defendant. Particularly, the formal and material prerequisites for a successful petition to retry the criminal case are subject to a detailed presentation and evaluation. Because no official statistics are kept regarding successful retrial processes in Germany, the actual number of judicial errors is primarily the subject of more or less well-founded estimates by legal practitioners and journalists. However, there are a few newer empirical studies devoted to different facets of the subject. These studies will be discussed in this article in order to outline the state of empirical research on the legal reality of the retrial procedure. Against this background, the article will ultimately highlight currently discussed reforms and subject these to a critical evaluation as well. The aim of the recent reform efforts is to add a ground for retrial to the disadvantage of the defendant for cases in which new facts or evidence indicate that the acquitted person was guilty. After detailed discussion, the proposal in question is rejected, inter alia for constitutional reasons.

Keywords: criminal proceedings, retrial in favour of the convicted, retrial to the disadvantage of the defendant, Germany, judicial errors

\section{Introduction}

The German Public Prosecutor's Office (Staatsanmaltschaft) likes to market itself (at least within its own ranks) as 'the most objective authority in the world'; pursuant to $\S 160(2)$ German Code of Criminal Procedure (StPO) it must 'ascertain both incriminating and exonerating circumstances', and pursuant to § 296(2) StPO it may 'make use of [the permitted legal recourse] in favour of the defendant' as well. If one adds to this the fact that in German criminal procedural law - unlike in procedural codes which are characterised by the

Michael Lindemann is Professor for Criminal Law, Criminal Procedure and Criminology at the Faculty of Law of Bielefeld University, Germany. Fabienne Lienau is Research Assistant at the Chair held by Michael Lindemann.

1. Under reference to a dictum of the Berlin Senior Public Prosecutor and later General Public Prosecutor Isenbiel; cf. J. Eisele and C. Trentmann, 'Die Staatsanwaltschaft - 'objektivste Behörde der Welt'?' [The German Public Prosecutor's Office - 'The Most Objective Authority in the World?'], 72 Neue Juristische Wochenschrift 2365, at 2366 (2019). notion of the adversarial system - the court is intended to have a quite active role in examination of the truth (cf. § 244(2) StPO), then one could come to the conclusion that there exist sufficient safety precautions against judicial errors even in such cases where the defendant is defended only poorly or not at all. As a number of spectacular errors of justice ${ }^{2}$ have shown in the recent past, wrongful convictions are nevertheless (one might be tempted to say: obviously) made in criminal cases even in German courtrooms. The following article therefore intends to focus on the question of what opportunities are available to suspects and the Public Prosecutor's Office in the event that they consider a legally effective criminal conviction to be incorrect. Based on a detailed investigation of the legal framework conditions and (somewhat scarce) knowledge of the legal reality, we will also pursue the issue of whether there is a need for legal reform regarding the mechanisms established in the German criminal process for correcting judicial errors. It must be pointed out at this juncture that there exist only limited corresponding opportunities for correction, and that the German legal system traditionally ${ }^{3}$ assigns a great deal of value to the institute of legal force. A peculiarity of German law is the possibility of proceeding against a legally effective criminal conviction with a constitutional complaint (Urteilsverfassungsbeschmerde) before the German Federal Court (Bundesverfassungsgericht). To do so, the complainant must plead that his basic rights or rights equal to his basic rights - e.g. the right to a legally competent judge pursuant to $\S 101(1)$ (2) Basic Law for the Federal Republic of Germany (Grundgesetz; GG) or the right to a legal hearing pursuant to $\S 103(1) \mathrm{GG}$ - have been violated, $\S 93(1)$ no. 4a GG, $\S 13$ no. 8a German Act on the Federal Constitutional Court (Bundesverfassungsgerichtsgesetz; BVerfGG). An extensive examination of the peculiarities of the constitutional complaint process is beyond the scope of this article and would also detract too much from the actual focus; we must therefore satisfy ourselves with a few

2. Examples can be found in R. Neuhaus, 'Fehlerquellen im Ermittlungsverfahren aus der Sicht der Verteidigung' [Sources of Errors in Investigations from the Perspective of the Defence], 35 Strafverteidiger 185 (2015); P. Velten, 'Fehlentscheidungen im Strafverfahren' [Wrong Decisions in Criminal Proceedings], 162 Goltdammer's Archiv für Strafrecht 387 (2015).

3. For an overview of the historical development of the law of retrials, cf. C. Arnemann, Defizite der Wiederaufnahme in Strafsachen [Shortcomings in Retrials in Criminal Cases] (2019), at 169 et seq.; S. Bayer, Die strafrechtliche Wiederaufnahme im deutschen, französischen und englischen Recht [The Retrial under Criminal Law in German, French and English Law] (2019), at 51 et seq. 
general remarks and refer interested readers to the relevant specialist literature. ${ }^{4}$ Instead, the focus of this article will be the correction mechanism inherent in the criminal process: the retrial that is governed under $\S 359$ et seq. StPO and which reverts the case back to the main proceedings if successful.

In the traditional reading, the legal force is interrupted in a retrial in the interest of a substantively correct decision. In one of the 'classic' textbooks on criminal procedural law, the basic idea of the retrial is summarised to the effect that, in exceptional cases, the legal force

must be withdrawn if facts which come to light after the decision cause the ruling to appear obviously incorrect in a manner that is unbearable for the sense of justice or ... if the sentence is not based on a minimum of procedural correctness. ${ }^{5}$

In the words of the German Federal Constitutional Court, the retrial instrument 'is intended to resolve the conflict between the principles of material justice and legal certainty, both of which are derived with constitutional effect from the rule of law' ${ }^{6}$

As Frister has shown in his commentary on $\S 359$ et seq. $\mathrm{StPO},{ }^{7}$ this formulation is in fact too imprecise in several aspects: thus, he first voices his doubt that 'even for the purpose of achieving substantive justice, a retrial is only sensible if an at least potentially more just decision can be expected from a new trial'. With increasing temporal distance to the act which is the subject of the proceedings, this could become questionable due to the usual clouding of sources of evidence over time. ${ }^{8}$ It must furthermore be taken into account that the faith of the general public in the rule of law, as is expressed in the topos of legal certainty, may also be damaged if new knowledge indicates that the legally effective ruling suffers from serious defects. ${ }^{9}$ A retrial on the basis of addi-

4. For a more comprehensive examination, cf. M. Jahn, C. Krehl, M. Löffelmann \& G. Güntge, Die Verfassungsbeschwerde in Strafsachen [The Constitutional Complaint in Criminal Cases] (2nd edn, 2017).

5. C. Roxin and B. Schünemann, Strafverfahrensrecht [Criminal Procedural Law] (29th edn, 2017), § 57.1 under reference to L. Greco, Strafprozesstheorie und materielle Rechtskraft [Criminal Procedure in Theory and Substantive Legal Force] (2015), at 883 et seq

6. BVerfG [German Constitutional Court], Resolution of the 2nd Chamber of the Second Senate of 14 September 2006 - 2 BvR 123/06 inter alia, NJW 2007, 207. Agreement in W. Schmidt, in R. Hannich (ed.), Karlsruher Kommentar zur StPO [Karlsruhe Commentary on the StPO] (8th edn, 2019), § 359.3; B. Schmitt, in: L. Meyer-Goßner and B. Schmitt (eds.), StPO mit GVG und Nebengesetzen [StPO with GVG and Ancillary Acts] (63rd edn, 2020), § 359.1.

7. H. Frister, in: J. Wolter (ed.), Systematischer Kommentar zur StPO [Systematic Commentary on the StPO] (5th edn, 2016), § 359.1 et seq.; see also H. Frister and T. Müller, 'Reform der Wiederaufnahme in Strafsachen' [Retrial Reform in Criminal Cases], 52 Zeitschrift für Rechtspolitik 101, at 102 (2019).

8. Frister, above n. 7, § 359.1 under reference to G. Grünwald, 'Die materielle Rechtskraft im Strafverfahren der Bundesrepublik Deutschland' [Substantive Legal Force in Criminal Proceedings in the Federal Republic of Germany], 86 Zeitschrift für die gesamte Strafrechtswissenschaft Beiheft 94, at 103 et seq. (1974)

9. Cf. in this regard also R.J. Norris, J.N. Weintraub, J.R. Acker, A.D. Redlich \& C.L. Bonventre, 'The Criminal Costs of Wrongful Convictions: Can We Reduce Crime by Protecting the Innocent?', 19 Criminology \& Public Policy 367, at 376 (2020). tional sources of knowledge could therefore be refused on the part of the public only on the grounds of the expenditure associated with a new trial, and the risk that evidence of an act that was actually committed may fail due to the passing of time; on the part of the defendant, the (individual) interest in not having to be subjected to a new criminal trial, protected by the principle of ne bis in idem ( $\$ 103(3) \mathrm{GG})$, must be taken into account. ${ }^{10}$ In Frister's opinion, what arises from this solidification of the range of interests is that the German legislator has correctly inserted the retrial to the disadvantage of the defendant and the retrial in favour of the convicted ${ }^{11}$ under $\S 359$ et seq. StPO into a differentiating regulation, and has particularly (only) permitted a retrial in the case of the former 'if a potentially more just decision can be expected in a new trial on the grounds of additional sources of knowledge' ( $\$ 359$ nos. 4, 5 StPO). ${ }^{12}$ In the course of this article we will, inter alia, investigate whether the law and the practice of retrying criminal cases in Germany are in fact suited to establishing an appropriate balance between the complex groups of interests outlined above. ${ }^{13}$

Following a brief outline of the constitutional complaint against a ruling in criminal cases as discussed above (2), the third section will initially present the status quo of the law of retrial in Germany (3). Afterwards, we provide an overview of the state of empirical research into the legal reality of the retrial procedure (4). On this basis, we will then highlight current proposed reforms and subject these to a critical evaluation (5). We offer a brief conclusion at the end (6).

\section{Constitutional Complaints in Criminal Cases}

As already indicated, besides the petition to retry the criminal case, there exists a further extraordinary legal remedy ${ }^{14}$ in Germany which allows proceedings against a criminal conviction that has already become legally effective: the constitutional complaint governed under $\S 93(1)$ no. 4a GG and $\S 13$ no. 8a, 90 et seq. BVerfGG. The Federal Constitutional Court is responsible for making a decision on the constitutional complaint but

10. Frister, above n. 7, § 359.2.

11. Regarding the linguistic differentiation based on $\S 362$ no. 4 StPO (Retrial to the disadvantage of the acquitted in case of a believable confession) which will also be taken as a basis in the following, cf. Frister, above n. 7, § 359.3 under reference to S. Brinkmann, Zum Anwendungsbereich der §§ 359 ff. StPO. Möglichkeiten und Grenzen der Fehlerkorrektur über das strafrechtliche Wiederaufnahmeverfahren [On the Scope of Application of $\S \S 359$ et seq. StPO. Opportunities and Limits of Correcting Errors via the Criminal Law Procedure of the Retrial] (2017), at 39-40.

12. Frister, above n. $7, \S 359.5$.

13. Frister's discussion of different approaches to reform in Frister, above n. 7, § 359.85 et seq.; $§ 362.3$ et seq.

14. On classification, cf. H. Bethge, in T. Maunz, B. Schmidt-Bleibtreu, F. Klein \& H. Bethge, Bundesverfassungsgerichtsgesetz [German Act on the Federal Constitutional Court], 58. EL Januar (2020), § 90.23. 
emphasises in its settled case law that it is not an 'instance of super-review' (a review of a review):

It is not the court's function to review, or even to standardise, the jurisprudence of the responsible specialised courts in their interpretation of the so-called 'ordinary law' (einfaches Recht) for the correctness of such. Rather, the court may only become involved if the decision of a court exhibits errors of interpretation which are based on an essentially incorrect view of the significance and scope of a basic right, or if the result of the interpretation is not congruent with the norms of basic law. (cf. Decision of the Federal Constitutional Court (BVerfGE) 18, 8592 f.; settled case law (stRspr) $)^{15}$

Although the constitutional complaint can by law be lodged by 'anyone' without engaging a lawyer, ${ }^{16}$ there exist a number of admissibility requirements which - at least in the interpretation of such by the Federal Constitutional Court - are not always easy to grasp even for professional lawyers. ${ }^{17}$ Thus, the court adds to the rule on exhaustion of legal remedies, which is explicitly standardised under $\S 90(2)(1) \mathrm{BVerfGG},{ }^{18}$ a (more comprehensive) principle of subsidiarity which demands that the complainant 'exploit all procedural possibilities available to him in order to effect a correction to a contested constitutional violation'. ${ }^{19}$ The complainant may not be referred to the bringing of wholly hopeless or clearly impermissible legal remedies; ${ }^{20}$ however, such remedies should also not be capable of impeding the course of the one-month period set for bringing the constitutional complaint as standardised under $\S 93(1)$ BVerfGG. ${ }^{21}$ As this brief insight into the case law of the Federal Constitutional Court shows, the court requires particularly complex prognostic considerations of the complainant in his efforts to satisfy the requirements for

15. BVerfG, Resolution of the 2nd Chamber of the Second Senate of 24 October 1999 - 2 BvR 1821/99, BeckRS 1999, 23087 n. 7.

16. In principle, proceedings before the Federal Constitutional Court are free of charge; however, a fee may be charged in case of misuse ( $\$ 34$ BVerfGG).

17. Cf. G. Lübbe-Wolff \& C. Geisler, ‘Neuere Rechtsprechung des BVerfG zum Vollzug von Straf- und Untersuchungshaft. Bericht mit Hinweisen zu einigen häufig übersehenen Erfolgsvoraussetzungen der Verfassungsbeschwerde' [Recent Case Law of the German Federal Constitutional Court on Enforcement of Criminal Custody and Remand. Report with Notes on Certain Frequently Overlooked Requirements for the Success of Constitutional Complaints], 24 Neue Zeitschrift für Strafrecht 478 , at 479 (2004); G. Lübbe-Wolff, 'Die erfolgreiche Verfassungsbeschwerde. Wie man das Unwahrscheinliche wahrscheinlicher macht' [The Successful Constitutional Complaint. How to Make the Unlikely More Likely], Anwaltsblatt 509, at 512 (2005). A comprehensive overview of the admissibility requirements for a constitutional complaint in criminal cases can be found in $M$. Jahn, in Jahn, Krehl, Löffelmann \& Güntge, above n. 4, n. 63 et seq.

18. $\S 90(2)(1)$ BVerfGG states, 'If legal recourse against the violation is permissible, then the constitutional complaint may only be brought after the legal recourse has been exhausted'.

19. BVerfGE 115, 81 (91 f.) under reference to BVerfGE 74, 102 (113); 104, 65 (70); for a more comprehensive examination, cf. Bethge, above n. $14, \S 90.401$ et seq.

20. Cf. BVerfGE 55, 154 (157); 70, 180 (186); 91, 93 (106); 102, 197 (198).

21. Cf. BVerfGE 5, 17 (19 f.); 19, 323 (330); 63, 80 (85); 91, 93 (106). subsidiarity. ${ }^{22}$ Similar difficulties can also be posed by a substantiation of the constitutional complaint which satisfies the requirements of the court: in the wording of the law, that the complainant must 'specify the right which has allegedly been violated, as well as the act or omission of the organ or authority by which the complainant claims his or her rights have been violated' ( $\$ 92$ BVerfGG). According to the Federal Constitutional Court, this results in an obligation to present or (comprehensively) reproduce the content of all affected decisions of the authorities or the courts and other documentation essential to the proceedings (written submissions, etc.), which in principle should allow the court to make a decision without referring to the case files. $^{23}$ This requirement too is not evident a priori from the law and appears liable to quickly overwhelm legal laypersons.

Regarding the justification of the constitutional complaint against a ruling in criminal cases, one can in principle look to the differentiation between violations of substantive law and violations of procedural law which is common in the review process (dem Revisionsverfahren). ${ }^{24}$ However, in doing so, one must take into account the reservation of the court, stated at the beginning of this section, that it is not an 'instance of super-review': errors in the application of 'ordinary law' are not sufficient in and of themselves; instead, a 'violation of a specific constitutional right' must be demonstrated. ${ }^{25}$ Whilst constitutional law is affected 'if the regulation violated determines the manner, in which the judge is called to and comes to reach a verdict', ${ }^{26}$ substantive legal errors may refer either to the unconstitutionality of the substantive law principles underlying the ruling or the unconstitutionality of the application of norms by the specialist courts. ${ }^{27}$ An example of a regulation declared void and incommensurate with the Grundgesetz for a constitutional complaint against a ruling due to a violation of the principle of definiteness ( $\$ 103(2) \mathrm{GG})$ is $\S 43$ a German Criminal Code (Strafgesetzbuch; StGB) (old version) which stipulated the imposition of a forfei-

22. Cf. on this dilemma, with respect to a complaint regarding the right to be heard (Anhörungsrüge) governed under ordinary law in, inter alia, § 33a, § 356a StPO, M. Lindemann, ‘ $\S 3$. Prozessgrundrechte und ihre Bedeutung für das Strafverfahren' [Basic Procedural Rights and their Importance in Criminal Proceedings], in E. Hilgendorf, H. Kudlich \& B. Valerius (eds.), Handbuch des Strafrechts, Band 7, Grundlagen des Strafverfahrensrechts [Criminal Law Handbook, Vol 7, Basics of Criminal Procedural Law] (2020), n. 36 et seq.

23. Cf. BVerfGE 88, 40 (45); 93, 266 (288); more comprehensive in LübbeWolff and Geisler, above n. 17, at 479; Lübbe-Wolff, above n. 17, at 515-6.

24. Cf. C. Krehl and M. Löffelmann in Jahn, Krehl, Löffelmann \& Güntge, n. 420.

25. Ibid.

26. M. Löffelmann, in Jahn, Krehl, Löffelmann \& Güntge, above n. 4, n. 421 This may relate to the right to a fair trial, effective legal protection, or the right to be heard, for example. For a comprehensive overview of the importance of the substantive basic rights and basic procedural rights for criminal proceedings, cf. $M$ Lindemann, ' $\$ 2$ and $\S 3$ ', in E. Hilgendorf, H. Kudlich \& B. Valerius (eds.), Handbuch des Strafrechts, Band 7, Grundlagen des Strafverfahrensrechts (2020).

27. Löffelmann, above n. 26, n. 553 et seq 
ture of assets. ${ }^{28}$ If a criminal judgement is based on a legal provision that is void or incompatible with the Basic Law, proceedings may be resumed even after the judgement has become final, as is stated in $\S 79(1)$ BVerfGG.

From a quantitative point of view, constitutional complaints against criminal convictions play a not too insignificant role in the overall occurrence of constitutional complaints lodged with the Federal Constitutional Court; ${ }^{29}$ however, it must also be taken into account that the proportion of successful constitutional complaints in recent years has consistently been below 2\% (2019: $1.54 \%) .{ }^{30}$

\section{Legal Framework for the Retrial Procedure}

Due to its inherent restriction to a genuinely constitutional control of the sentencing practice of the criminal courts, the constitutional complaint is of somewhat secondary importance for the context of correcting judicial errors discussed here. What is significantly more relevant from a thematic perspective is the retrying of a criminal trial, the legal framework conditions of which will therefore be considered in more detail below.

\subsection{Grounds for a Retrial}

The grounds for retrying a case can be found under $\S 359$ and $\S 362$ StPO; here, the former norm governs the retrial in favour of the convicted and the latter to the disadvantage of the defendant.

\subsubsection{Systematics}

To improve understanding, we should first provide a systematic overview of the legally standardised grounds for retrial: thus, a retrial is possible both in favour of the convicted and to the disadvantage of the defendant due to criminal acts committed in connection with the passing of the sentence (so-called retrial propter falsa, § 359 no. 1-3, 362 no. 1-3 StPO). These may consist in the falsification of a document that was crucial to the decision, a false statement made by a witness or expert and the criminal violation of public duty by a judge or juror involved in the reaching of a verdict - e.g. the acceptance of a benefit, corruption or perverting the course of justice. Moreover, a retrial in favour of the convicted can also be held in the following cases: annulment of a civil judgement which the criminal conviction is based on ( $\$ 359$ no. 4 StPO); the bringing of new, favourable facts or evidence (so-called retrial propter nova; $\$ 359$ no. 5 $\mathrm{StPO})$; and in cases where the ruling is based on a violation of the European Convention on Human Rights

28. Cf. BVerfGE 105, 135 .

29. Of the 5,158 constitutional complaints lodged in 2019, 1,322 were lodged against decisions of the criminal courts; cf. BVerfG, Annual Statistics 2019, accessible online www.bverfge.de.

30. For a comparison across several years, see BVerfG, Annual Statistics 2019, accessible online www.bverfge.de.
(ECHR) identified by the ECtHR ( $\$ 359$ no. 6 StPO). Pursuant to $\$ 79(1) \mathrm{BVerfGG}$, a retrial in favour of the convicted shall ultimately be considered if the ruling is based on a norm or the interpretation of a norm which the Federal Constitutional Court has declared incommensurate with the Grundgesetz. A retrial to the disadvantage of the defendant is possible not only in the cases mentioned at the outset, but also in the event that the defendant gives a believable confession ( $\$ 362$ no. 4 $\mathrm{StPO})$. On the other hand, a retrial to the disadvantage of the defendant in the event of new facts or evidence is excluded in principle. The law provides for an exception only in the event of closure of proceedings by means of a legally effective penalty order (which is only based on a summary examination of the facts ${ }^{31}$ ) if the new facts or evidence are suitable for justifying the sentencing of a crime ${ }^{32}(\$ 373 \mathrm{a}(1) \mathrm{StPO}) .{ }^{33}$

\subsubsection{Grounds for a Retrial in Favour of the Convicted}

If one examines the opportunities for effecting a retrial in favour of the convicted in more detail, then it initially becomes clear that the grounds standardised under $\S 359$ nos. 1 to $4 \mathrm{StPO}$ are regularly only considered in the event that new facts or evidence comes to light. From a technical perspective, therefore, these are special cases of $\S 359$ no. 5 StPO. ${ }^{34}$ However, the demand to strike $\S 359$ nos. 1 to 4 , which is occasionally inferred from this assessment, ${ }^{35}$ must be rejected. In doing so, we must first consider that $\$ 359$ no. $3 \mathrm{StPO}$, which is related to the criminal violation of public duty by a judge or juror involved in the ruling, is designed as absolute grounds for a retrial - unlike the other variations of $\S 359 \mathrm{StPO}$, here there is no demand for proof of the effect of the defect on the content of the ruling. The convicted person would thus be in a worse position if $\S 359$ no. 3 StPO were stricken. ${ }^{36}$ Arguing against a striking of $§ 359$ nos. 1, 2 and $4 \mathrm{StPO}$, it is stated that here too the legal situation for the convicted would be effectively made worse in the light of the generally very restrictive han-

31. The penalty order proceedings governed under $\S 407$ et seq. StPO are written proceedings, in which the Public Prosecutor's Office submits a written proposal for a decision to the court. Pursuant to $\S 408(3)(1)$ StPO, 'the judge shall comply with the application of the public prosecution office if he has no reservations about issuing the summary penalty order'. The defendant then has the opportunity to lodge an objection within two weeks of notification of the penalty order ( $\$ 410(1)(1)$ StPO) and thus to force (largely) regular main proceedings. If no legally effective objection is made, then the penalty order is equal to a legally effective criminal conviction (§ 410(3) StPO).

32. Pursuant $\S 12(1)$ StGB, crimes are 'unlawful acts which are subject at least to a prison sentence of one year or more'.

33. For criticism of this regulation, cf. Frister, above n. 7, § 373a.5.

34. In the sense of A. Engländer and T. Zimmermann, in C. Knauer (ed.), Münchener Kommentar zur StPO, Band 3/1 [Munich Commentary on the StPO, vol 3/1] (2019), § 359.2; see also Frister, above n. 7, § 359.4; Schmidt, above n. 6, § 359.3 .

35. P. Deml, Zur Reform der Wiederaufnahme des Strafverfahrens [On Retrial Reform in Criminal Proceedings] (1979), at 103 et seq.; J. Meyer, Wiederaufnahmereform: Eine rechtsvergleichende Untersuchung zur Reform des Rechts der Wiederaufnahme des Strafverfahrens [Retrial Reform: A Legal Comparative Examination of the Reform of the Right to Retrial in Criminal Proceedings] (1977), at 93 et seq

36. Cf. Engländer and Zimmermann, above n. 34, § 359.2 
dling of $\$ 359$ no. 5 StPO by the case law - as discussed in more detail later in this section. ${ }^{37}$

According to $\$ 359$ no. $1 \mathrm{StPO}$, a retrial in favour of the convicted shall be considered if a document presented in the main proceedings as genuine was not genuine or was falsified to his disadvantage'. In this respect, the term document under substantive law, in the sense of $\S 267$ StGB (Falsification of documents), must be taken as a basis; ${ }^{38}$ accordingly, a document is 'any physical embodiment of thoughts which is suitable and intended for use as evidence in legal communication, and which states its author'. ${ }^{39}$ Sometimes, an analogous application to technical recordings in the sense of $\$ 268 \mathrm{StGB}$ (e.g. a truck's black box) is also considered. ${ }^{40}$ The document is not genuine if the declaration contained therein does not originate from the person indicated as its author. ${ }^{41}$ The bringing of a document to the disadvantage of the convicted must be assumed if it cannot be excluded that the document influenced the ruling to the disadvantage of the convicted. ${ }^{42}$ It is contested whether $\$ 364$, clause 1 StPO, which, for petitions for retrial based on the claiming of a criminal act, requires the presence of a legally effective sentence on the grounds of this act or nonprosecution of such which is not supported by a lack of evidence, is applicable to $\S 359$ no. 1 StPO. The prevailing opinion rejects such by referring to the wording of $\S 359$ no. 1 StPO which deviates from $\S 359$ nos. 2 and 3 $\mathrm{StPO}$ and specifically contains no reference to a requirement of criminal liability. ${ }^{43}$

According to $\S 359$ no. $2 \mathrm{StPO}$, a retrial in favour of the convicted shall furthermore be considered

if the witness or expert is guilty of wilfully or negligently violating their oath or of making an intentionally false statement under oath in a statement or

37. Cf. Frister, above n. 7, § 359.85. However, § 359 no. 5 StPO is given a catch-all function in those cases where the petition for retrial is based on the claiming of a criminal act, but where no legally effective sentence has yet been rendered against this act ( $\S 364$, clauses 1, 2 StPO); cf. here, Engländer and Zimmermann, above n. 34, § 359.2.

38. Prevailing opinion; cf. R. Eschelbach, in B. von Heintschel-Heinegg \& J. Bockemühl (eds.), KMR - Kommentar zur Strafprozessordnung [Commentary on the German Code of Criminal Procedure], 97. EL May (2020), § 359.38; J. Kaspar, in H. Satzger, W. Schluckebier \& G. Widmaier (eds.), Strafprozessordnung [German Code of Criminal Procedure] (4th edn, 2020), § 359.10; Schmitt, above n. 6, § 359.4; T. Singelnstein, in J. Graf (ed.), BeckOK-Strafprozessordnung [Beck Online Commentary on German Code of Criminal Procedure] (36th edn, as at: 1 January 2020), § 359.8; conversely, in favour of establishing a procedural concept of a document (restriction to readable written documents signed by hand according to § 249), cf. K. Marxen and F. Tiemann, Die Wiederaufnahme in Strafsachen [Retrials in Criminal Cases] (3rd edn, 2014), n. 137.

39. Singelnstein, above n. $38, \S 359.8$ with citations.

40. For example, Kaspar, above n. 38, § 359.10; Schmidt, above n. 6, $\S 359.6$; Schmitt, above n. 6, § 359.5; conversely, Engländer and Zimmermann, above n. 34, § 359.18; Eschelbach, above n. 38, § 359.41.

41. Cf. Engländer and Zimmermann, above n. 34, § 359.19; Frister, above n. 7, § 359.19; each with citations.

42. Cf. Kaspar, above n. 38, § 359.10.

43. Cf. Eschelbach, above n. 38, § 359.57; J. Kaspar, above n. 38, $\S 359.11$; each with citations; generally also BGH [German Federal Supreme Court], Resolution of 20 December 2002 - StB 15/02, NStZ 2003, 678 (679); alternative opinion, Frister, above n. 7, § 359.20; Schmidt, above n. 6, § 359.9 . appraisal presented to the disadvantage of the convicted.

Since the assertion of these grounds for a retrial also claims the occurrence of a criminal act, the requirements of $\S 364$, clause 1 StPO (legally effective judgement or non-prosecution which is not based on a lack of evidence) must be present. ${ }^{44}$ Here too, an effect to the disadvantage of the convicted must be assumed if a negative influence of the witness statement or expert appraisal on the ruling cannot be excluded; ${ }^{45}$ according to the prevailing opinion, however, it should not be necessary that the ruling is based on that part of the statement or appraisal which has been asserted as incorrect. ${ }^{46}$ Thus, a retrial in favour of the convicted can also be considered pursuant to $\S 359$ no. 3 stop

if a judge or lay judge who participated in reaching the judgment was guilty of a culpable breach of his official duties in relation to the case, unless the violation was caused by the convicted person himself.

The criminal act must have been committed 'with respect to the case', and may not simply have occurred 'on the occasion' of the activities of a judge - such as in the form of insulting the defendant. ${ }^{47}$ The direct or indirect causing of the violation of public duty by the convicted (e.g. by bribing the judge who is acting contrary to his obligations) excludes the application of $\$ 359$ no. 3 StPO. ${ }^{48}$ What is criticised is the very high hurdle for a retrial presented by the requirement for a criminal act - such as perverting the course of justice ( $\$ 339$ StGB), accepting benefits or corruption $(\S 331, \S 332$ StGB), unlawful detention or coercion $(\S 239, \S 240$ StGB); however, only the legislator would have the authority to reduce such to any form of conscious violation of public duty with respect to the case as has been proposed (and is certainly worth considering). ${ }^{49}$ The restriction to persons directly involved in the reaching of a verdict is also rightly questioned since judicial errors - as shown not least of all by international research into this topic ${ }^{50}$ - can also be traced back to the

44. Cf. Kaspar, above n. 38, § 359.13

45. Cf. Engländer and Zimmermann, above n. 34, § 359.27; Frister, above n. 7, § 359.25; J. Kaspar, above n. 38, § 359.13.

46. Higher County Court Düsseldorf, Resolution of 6 December 1949 - Ws 250/49, NJW 1950, 616; Schmitt, above n. 6, § 359.12; alternative opinion Engländer and Zimmermann, above n. 34, § 359.26; Frister, above n. 7, § 359.25 (in case of lack of basis, consideration within framework of $\S 359$ no. 5 StPO only).

47. Cf. Engländer and Zimmermann, above n. 34, § 359.30; Schmidt, above n. 6, § 359.13.

48. The mere knowledge that a third party has effected the violation of public duty without any personal involvement of the convicted person is harmless, however; cf. Engländer and Zimmermann, above n. 34, § 359.31; Schmidt, above n. 6, § 359.14 .

49. Demanded by Greco, above n. 5, at 944 and 954; generally in agreement, Kaspar, above n. 38, § 359.16.

50. The significance of misconduct on the part of the police and the public prosecutor for the occurrence of judicial errors is particularly well documented for the US justice system (cf. R. Covey, 'Police Misconduct as a Cause of Wrongful Convictions', 90 Washington University Law Review 1133 (2013); J. Petro and N. Petro, 'The Prosecutor and 
misconduct of other persons involved in the proceedings (in the present context, in particular: the police or the public prosecutor's office). ${ }^{51}$

$\S 359$ no. 4 StPO also permits a retrial in favour of the convicted if a civil judgement, which the criminal conviction is based on, is annulled by another legally effective ruling'. In the prevailing opinion, the scope of application of these grounds for a retrial should cover not just the civil judgements explicitly mentioned in the norm, but also judgements under labour, social, administrative and financial law. ${ }^{52}$ If, on the other hand, another criminal conviction utilised in the reaching of a verdict is annulled, then the only possible path should be via $\$ 359$ no. 5 StPO. ${ }^{53}$ However, if one assumes - as holders of the prevailing opinion do - that a criminal conviction is always 'founded' on the earlier decision in the sense of $\S 359$ no. 4 StPO if this decision was used as documentary grounds, then it is not clear why this should not also apply for earlier criminal convictions which are introduced to the main proceedings by means of public reading and utilised in the ruling. ${ }^{54}$ The same applies against the prevailing opinion ${ }^{55}$ for the annulment of administrative documents utilised in the criminal conviction since the failure to obey state authority, which still remains even after the elimination of an unlawful administrative document, regularly does not constitute any wrongdoing worthy of punishment. ${ }^{56}$

Notwithstanding the restrictive practical application already mentioned, the retrial in favour of the convicted on the grounds of the bringing of new facts or evidence ( $\$ 359$ no. 5 StPO) has the greatest practical significance. ${ }^{57}$ According to the regulation, designed as a general clause, ${ }^{58}$ a retrial in favour of the convicted shall be considered

Wrongful Convictions: Misplaced Priorities, Misconduct, Immunity and Remedies', in C. R. Huff and M. Killias (eds.), Wrongful Convictions \& Miscarriages of Justice (2013) 91; according to the National Registry of Exonerations, 'official misconduct' contributed to the sentencing in 1,425 of the 2,647 cases recorded therein; cf.www.law.umich.edu/ special/exoneration/Pages/ExonerationsContribFactorsByCrime.aspx; accessed 23 June 2020, but may also constitute a not inconsiderable factor in other legal systems - including the German system (cf. M. Killias and R. Huff, 'Wrongful Convictions and Miscarriages of Justice: What Did We Learn?', in C. R. Huff \& M. Killias (eds.), Wrongful Convictions \& Miscarriages of Justice (2013) 373, at 380).

51. In the sense of Frister, above n. 7, § 359.26.

52. Schmidt, above n. 6, § 359.15; Singelnstein, above n. 38, § 359.18; Schmitt, above n. 6, § 359.17; dissent in Eschelbach, above n. 38, $\S 359.29$.

53. Cf. Engländer and Zimmermann, above n. 34, § 359.33; Schmidt, above n. 6, § 359.15; Schmitt, above n. 6, § 359.17.

54. For example, Frister, above n. 7, § 359.33; Kaspar, above n. 38, $\S 359.20$.

55. Cf. BGHSt 23, 86 (94); Schmidt, above n. 6, § 359.15; Schmitt, above n. $6, \S 359.17$.

56. In the sense of Engländer and Zimmermann, above n. 34, § 359.33; Frister, above n. 7, § 359.34a; ultimately, also Kaspar, above n. 38, $\S 359.20$; Singelnstein, above n. 38, § 359.18.

57. In the sense of Engländer and Zimmermann, above n. 34, § 359.2; Eschelbach, above n. 38, § 359.4; G. Strate, 'Der Verteidiger in der Wiederaufnahme' [The Defence Counsel in Retrials], 19 Strafverteidiger 228, at 229 (1999).

58. Frister, above n. 7, § 359.35 if new facts or evidence were produced which, independently or in connection with the evidence previously taken, tend to support the defendant's acquittal or, upon application of a more lenient criminal provision, a lesser penalty or a fundamentally different decision on a measure of reform and prevention. (Maßregel der Besserung und Sicherung)

On the term (nem) facts, the Federal Constitutional Court states:

Facts shall be understood as existing, identifiable occurrences or circumstances which belong to the past or the present. Whether a fact is new or not shall be judged solely according to whether or not the court has already utilised it. Therefore, in principle new is everything which the court has not taken as a basis for forming its opinion, even if it could have taken such as a basis. ${ }^{59}$

Therefore, in order to assess the question of whether a fact is new, one must refer to the time of decision, meaning the conclusion of deliberation in case of convictions. ${ }^{60}$ Evidence discussed in the main proceedings may also be new if the court (in violation of its obligation to assess the evidence exhaustively and completely as arises from $\$ 261 \mathrm{StPO})^{61}$ has not taken such as the basis for its decision. ${ }^{62}$ It must be taken into account though that criminal courts are not obliged to address every taking of evidence made in the main proceedings within the context of its grounds for the ruling. ${ }^{63}$ However, in the failure to mention a piece of evidence which is substantial with respect to the basis of facts for the decision, one may see an indication of a failure to take such into account. ${ }^{64}$ Therefore, the sentence, facts are 'not new (only) because they have not been mentioned in the ruling', which one finds in one of the leading commentaries on the Criminal Procedural Code, does not apply in this generality. ${ }^{65}$ So-called legal facts, such as the repealing of a law or amendment to the interpretation of such, are covered by $\S 359$ no, 5 StPO just as little as simple procedural errors or errors of substantive law - the retrial is not a 'review without time limit'. ${ }^{66}$

59. BVerfG, Resolution of the 2nd Chamber of the Second Senate of 19 July 2002 - 2 BvR 18/02, 2 BvR 76/02, StV 2003, 225.

60. Cf. Engländer and Zimmermann, above n. 34, § 359.45; Kaspar, above n. 38, § 359.25; Marxen and Tiemann, above n. 38, n. 178.

61. See here Y. Ott and R. Hannich (ed.), Karlsruher Kommentar zur StPO (8th edn, 2019), § 261.56 et seq.

62. In agreement, for example, Engländer and Zimmermann, above n. 34, $\S$ 359.44; Frister, above n. 7, § 359.46; Schmidt, above n. 6, § 359.24; alternative opinion, Schmitt, above n. 6, § 359.30 .

63. Cf. Frister, above n. 7, § 359.47 .

64. Ibid., § 359.47; differentiating, also Engländer and Zimmermann, above n. 34, § 359.48; Eschelbach, above n. 38, § 359.161.

65. Schmitt, above n. 6, § 368.5; similarly, Singelnstein, above n. 38, $\S 359.27$.

66. Kaspar, above n. 38, § 359.24; see also Frister, above n. 7, § 359.38; Schmidt, above n. 6, § 359.19; Singelnstein, above n. 38, § 359 Rn. 22; for inclusion of facts of the case related to the proceedings, Engländer and Zimmermann, above n. 34, § 359.41; for extension to obvious errors of law de lege ferenda, M.P. Waßmer, 'Die Wiederaufnahme in Strafsachen - Bestandsaufnahme und Reform' [The Retrial in Criminal 
What is considered (new) evidence is the formal evidence of the StPO (witnesses, experts, documents and visual inspections), but not the defendant himself. ${ }^{67}$ Personal evidence means the persons themselves and not their declarations; thus an amended statement is not new evidence, but rather, under certain circumstances, a new fact. ${ }^{68}$

According to $\$ 359$ no. $6 \mathrm{StPO}$, a retrial in favour of the convicted shall ultimately be considered

if the European Court of Human Rights has asserted a violation of the European Convention for the Protection of Human Rights and Fundamental Freedoms or its protocols, and has based the ruling on this violation.

The regulation takes account of the fact that decisions adopted by the ECtHR do not have any direct cassatory effect, and thus acts of law adjudged to be in contravention of the convention still require annulment by the national courts. ${ }^{69} \mathrm{~A}$ requirement for a retrial according to $\S 359$ no. $6 \mathrm{StPO}$ is that the criminal law sentence is based on a violation of the Convention on Human Rights or its protocols asserted by the ECtHR; however, here, just as in the case of a review ( $\$ 337 \mathrm{StPO}),{ }^{70}$ the possibility alone that the decision would have been different if the Convention had not been violated is sufficient. ${ }^{71}$ According to the wording of $\S 359$ no. $6 \mathrm{StPO}$, which is relevant in this respect, a retrial shall only be considered if contravention of the Convention has been explicitly asserted by the ECtHR; the analogous application to contraventions of the Convention which are 'clear' but not (yet) asserted by the ECtHR, which is sometimes ${ }^{72}$ advocated for, must be rejected. ${ }^{73}$ The same (in any case de lege lata) applies for the carrying over of the result contested by a convicted person before the ECtHR to other cases of the same type; pursuant to $\S 359$ no. 6 StPO, only persons who themselves have contested a final decision before the ECtHR are permitted to make a petition. ${ }^{74}$ It is an entirely different matter though

Cases - Survey and Reform], 24 Juristische Ausbildung 454, at 460 (2002).

67. Cf. Kaspar, above n. 38, § 359.27; Schmidt, above n. 6, § 359.23. In the opinion of Frister, above n. 7, § 359.36 this constitutes uniform grounds for a retrial; the differentiation between facts and evidence is obsolete.

68. Cf. Schmidt, above n. 6, § 359.23; Singelnstein, above n. 38, § 359.22.

69. Cf. Kaspar, above n. 38, § 359.39 .

70. On the requirement for a basis in the sense of $\S 337$ StPO cf. only Schmitt, above n. 6, § 337.37 with citations.

71. Cf. Engländer and Zimmermann, above n. 34, § 359.68; Frister, above n. $7, \S 359.74$. The basis must be denied in particular if compensation for a violation of the Convention has already been made in specialist court proceedings.

72. For example, from County Court Ravensburg, Resolution of 4 September 2000 - 1 Qs 169/00, NStZ-RR 2001, 115

73. Cf. Kaspar, above n. 38, § 359.40; Schmidt, above n. 6, § 359.40 .

74. Cf. Eschelbach, above n. 38, § 359.219; Frister, above n. 7, § 359.75; Schmidt, above n. 6, § 359.40; Schmitt, above n. 6, § 359.52; conversely, for extension of the applicable $\S 359$ no. 6 StPO to parallel cases Engländer and Zimmermann, above n. 34, § 359.69; R. Esser, ‘Die Umsetzung der Urteile des Europäischen Gerichtshofs für Menschenrechte im nationalen Recht - ein Beispiel für die Dissonanz völkerrechtlicher Verpflichtungen und verfassungsrechtlicher Vorgaben?' [Imple- whether this restriction is still appropriate - in fact, there are good reasons to call for an extension of the grounds for retrial to sentences which are based on a legal norm or legal opinion declared in another case to be in contravention of the Convention is demanded de lege ferenda. ${ }^{75}$

Thus, the legal situation with respect to decisions of the ECtHR would ultimately be adapted to the legal situation which applies for decisions of the Federal Constitutional Court pursuant to § 79(1) BVerfGG. According to this regulation, a retrial is permitted against any criminal conviction

based on a legal provision which was declared to be incompatible with the Grundgesetz or which was voided pursuant to $\S 78$, or which was based on the interpretation of a legal provision which the Federal Constitutional Court declared to be incompatible with the Grundgesetz.

Insofar as the law also requires that a decision here be based on the unconstitutional norm or interpretation of the norm, again the standard developed for review according to $\$ 337$ StPO should be used. ${ }^{76}$

\subsubsection{Grounds for a Retrial to the Disadvantage of the Defendant}

The grounds for a retrial to the disadvantage of the defendant standardised under $\S 362$ nos. 1 to 3 StPO largely correspond in content to the grounds stipulated for a retrial in favour of the convicted under $\$ 359$ nos. 1 to $3 \mathrm{StPO}$. In principle, one can refer to the discussions on these in this regard. However, unlike $\S 359$ no. 3 StPO, the fact that the defendant has caused the criminal violation of public duty is not given any significance in the context of $\S 362$ no. 3 StPO. ${ }^{77}$ And unlike $\S 359$ StPO, an extension of the scope of application of the grounds for retrial by analogy is otherwise rejected on the grounds of the principle of ne bis in idem anchored constitutionally in $\S 103(3) \mathrm{GG}^{78}$

$\S 362$ StPO does not contain any grounds for a retrial which correspond to those contained in $\S 359$ no. 4 StPO (annulment of a civil law decision). Conversely, the grounds for retrial standardised in $\$ 362$ no. 4 StPO,

mentation of Rulings of the European Court of Human Rights in National Law - An Example of Dissonance between Public International Law Obligations and Constitutional Law Stipulations?], 25 Strafverteidiger 348, at 354-5 (2005); T. Weigend, 'Die Europäische Menschenrechtskonvention als deutsches Recht - Kollisionen und ihre Lösung' [The European Convention on Human Rights as German Law - Conflicts and How to Solve Them], 20 Strafverteidiger 384, at 388 (2000).

75. In the sense of Frister, above n. 7, § 359.75a; Kaspar, above n. 38, $\S 359.42$; M. Marxen, 'Ende gut, aber keineswegs alles gut - Defizite des strafrechtlichen Wiederaufnahmeverfahrens' [Good in the End but Far from All Good - Shortcomings in the Retrial Procedure under Criminal Law], in P.-A. Albrecht, et al. (eds.), Festschrift für Walter Kargl [Festschrift for Walter Kargl] (2015) 323, at 331.

76. Cf. Engländer and Zimmermann, above n. 34, § 359.81 .

77. Cf. Singelnstein, above n. 38, § 362.4.

78. This applies, for example, for the analogous application of $\S 359$ no. 1 StPO to technical recordings in the sense of $\S 268$ StGB that is sometimes considered (cf. substantiation of the current debate in fn. 40). As a whole, see Kaspar, above n. 38, § 362.4. 
namely the giving of a believable confession (obviously), have no counterpart in $\S 359$ StPO. According to $\$ 362$ no. $4 \mathrm{StPO}$, a retrial to the disadvantage of the defendant shall be considered if a credible confession to the criminal act is given by the acquitted party in or outside the court'. To establish theses grounds for a retrial, it was crucial to assume that

the people's legal consciousness (could) be misled if a criminal, after being acquitted due to a lack of evidence, may accuse himself or even boast of the crime without punishment. ${ }^{79}$

Here too, the limited wording must be strictly observed; since it talks of the 'acquitted', application to confessed convicts with the aim of a harsher penalty cannot be considered. ${ }^{80}$ Insofar as a measure of reform and prevention (which is not connected with an accusation of guilt) was imposed according to $\S 61$ et seq. StGB alongside an acquittal, this does not prevent a retrial. ${ }^{81}$ According to the wording of the norm, the confession must furthermore come personally from the acquitted person named in the petition for retrial; testimonial confessions of purported accessories to the act are not sufficient. ${ }^{82}$ If one takes the requirement for a 'confession to a criminal act' seriously, then one must also demand that the presence of all prerequisites for criminal liability (including unlawfulness and guilt) arises a priori from the statement of the acquitted; the rationale of the norm also speaks in favour of this. ${ }^{83}$ The prevailing opinion, however, considers it sufficient that the defendant 'admits to the external facts of the case and his perpetration thereof ${ }^{84}$ Ultimately, the confession must be 'credible' according to $\$ 362$ no. $4 \mathrm{StPO}$; this is interpreted to the effect that the facts admitted to are logically possible in law and must correspond to lived experience. ${ }^{85}$

\subsection{Procedure}

The following section is devoted to a presentation of the retrial procedure. The procedure is broken down into a review of the permissibility and merit of the petition, and in the case of a merited petition ends in a repeating of the main proceedings. ${ }^{86}$

79. Draft 1873, Reasoning of $\S 278$, clause 174; cited in Frister, above n. 7 , $\S 362.1$.

80. Cf. Engländer and Zimmermann, above n. 34, § 362.11; Frister, above n. 7, § 362.14; Schmidt, above n. 6, § 362.9.

81. Cf. Engländer and Zimmermann, above n. 34, § 362.12; Frister, above n. 7, § 362.15.

82. Cf. Engländer and Zimmermann, above n. 34, § 362.13 .

83. See here ibid.; Frister, above n. 7, § 362.16; Kaspar, above n. 38 , $\S 362.10$.

84. Schmidt, above n. 6, § 362.11; also Schmitt, above n. 6, § 362.5; each with citations

85. Cf. Engländer and Zimmermann, above n. 34, § 362.16; Schmidt, above n. 6, § 362.14; see also Frister, above n. 7, § 362.18, who moreover demands an overwhelming likelihood of sentencing in the sense of the suspicion of an offence otherwise duly sufficient for the lodging of an appeal and opening of the main proceedings (§ 170(1), § 203 StPO).

86. Cf. here also the overview in Bayer, above n. 3, at 168 et seq. A comprehensive illustration of the review of permissibility and merit can be found in Marxen and Tiemann, above n. 38, n. 11 et seq

\subsubsection{Reviem of the Permissibility of the Petition for Retrial (Additionsverfahren)}

The so-called Additionsverfahren (lit. additions process), in which the permissibility of a petition for a retrial is reviewed, is essentially governed under $\$ 366$ et seq. StPO. Many petitions for a retrial in favour of the convicted obviously fail at this stage in the procedure; the reason for this is (also) found in a generally restrictive handling of the relevant regulations by the courts who are not necessarily open to a critical review of their decisions. ${ }^{87}$

Pursuant to $§ 366(1)$ StPO, 'the statutory ground for reopening proceedings and the evidence' must be specified in the petition - which is not subject to a time limit. ${ }^{88}$ The petition for a retrial may only be based on the presence of one of the legally standardised grounds for retrial; it is impermissible if it is aimed exclusively at effecting a different sentencing on the grounds of the same law or a reduction in sentence due to significantly reduced criminal responsibility ( $\$ 21 \mathrm{StGB}$; cf. $§ 363(1)$, (2) $\mathrm{StPO}){ }^{89}$

If the defendant (or a close member of his family in case of his death, $\S 361(2)$ StPO) is seeking a retrial in his favour, then he may bring the 'application only in the form of a written document signed by defence counsel or by a lawyer, or orally to be recorded by the court registry' ( $\$ 366(2) \mathrm{StPO}) .{ }^{90}$ Whilst the finding of a specialist lawyer who is in principle willing to take on the mandate of a retrial should not be an insurmountable obstacle, the financing of the mandate from the defendant's own resources often poses significant and not infrequently insurmountable obstacles to an effectively convicted person. ${ }^{91}$ Under certain conditions, therefore, the appointing of counsel is stipulated for the retrial procedure or upon preparations for such ( $§ 364 a, b$ StPO). The latter is then the case pursuant, inter alia, to $\S 364 b(1)(1)$ no. 1 StPO if 'there are sufficient factual indications that making certain inquiries will bring to light facts or evidence which may substantiate the admissibility of an application to reopen the proceedings'. Counsel is thus authorised to undertake investiga-

87. Cf. M. Bock et al., 'Die erneute Wiederaufnahme des Strafverfahrens' [The Retrying of Criminal Proceedings], 160 Goltdammer's Archiv für Strafrecht 328 (2013); R. Eschelbach, A. Geipel, M. Hettinger, L. Meller \& F. Wille, 'Plädoyer gegen die Abschaffung der Wiederaufnahme des Strafverfahrens' [Against the Elimination of the Retrying of Criminal Proceedings], 165 Goltdammer's Archiv für Strafrecht 238 (2018); Frister and Müller, above n. 7, at 104; Marxen, above n. 75, at 323; Marxen and Tiemann, above n. 38, n. 2; Strate, above n. 57, at 228.

88. Cf. Engländer and Zimmermann, above n. 34, § 366.19; see also Marxen and Tiemann, above n. 38, n. 14, who rightly point out that a practical restriction arises from the fact that the bringing of new evidence gets harder and harder over time.

89. For the striking of $\S 363(2)$ StPO de lege ferenda, Frister, above n. 7, § 363.21-22: Frister and Müller, above n. 7, at 104; for criticism, also J. Kaspar and C. Arnemann, 'Die Wiederaufnahme des Strafverfahrens zur Korrektur fehlerhafter Urteile' [The Retrying of Criminal Proceedings to Correct Wrongful Rulings], 34 Recht \& Psychiatrie 58, at 63 (2016).

90. Cf. here Roxin and Schünemann, above n. 5, § 57.13. Here, in the case of signing by a lawyer, it is required that said lawyer assumes full responsibility for the content, and has been involved in its creation; cf. Kaspar, above n. 38.

91. See here also Strate, above n. 57, at 228 
tions independently (such as questioning witnesses), but of course in doing so does not have the coercive powers which are available to the criminal investigation authorities. ${ }^{92}$ Pursuant to $\S 364 b(1)(1)$ no. 3 StPO, counsel shall also be appointed if 'the convicted person is unable to hire counsel at his own costs without impairing the support which he and his family require'. For the event of appointment according to $\S 364 \mathrm{~b}(1)(1) \mathrm{StPO}, \S 45(4)(1)$ German Act on Remuneration of Lawyers (Rechtsanmaltsvergütungsgesetz; RVG) stipulates that the lawyer appointed shall have a claim against the state treasury even if he ultimately advises against the lodging of a petition for retrial; according to $\$ 46(3)(1) \mathrm{RVG}$, this claim to remuneration also covers expenses which are incurred due to the investigations undertaken regarding preparation for the retrial procedure. ${ }^{93}$ In quite general terms, the legislator, with $\S 364 a, b$ StPO, takes account of the fact that many (in particular incarcerated) convicted persons are personally unable or able only to a very limited extent to exercise their rights competently in advance of the retrial procedure and during execution of such. $^{94}$

The authority of the court is governed by special provisions of the German Judicature Act (Gerichtsverfassungsgesetz; GVG; $§ 367(1)(1)$ StPO). Pursuant to $\S 140 \mathrm{a}(1)$ (1) GVG, the petition for retrial is decided on by 'another court with the same substantive jurisdiction as the court against whose decision the application for the reopening of proceedings is directed'. Pursuant to $\S 368(1)$ StPO, this court shall review whether the formal requirements have been adhered to, whether legally stipulated grounds for retrial have been asserted and whether suitable evidence has been indicated. If any of these conditions of permissibility is lacking, then the petition is rejected by the court as impermissible.

The requirements that must be placed on the suitability of evidence required by $\S 368(1)$ StPO are contested at this stage in the procedure. This debate is significant above all for the assessment of a petition for retrial based on $\S 359$ no. 5 StPO. ${ }^{95}$ According to the appropriate interpretation, those criteria which are followed in the assessment of petitions to take evidence in contentious proceedings (cf. $§ 244(3)-(5)$ StPO) shall be taken as a basis here. ${ }^{96}$ Accordingly, evidence shall also be considered unsuitable in the sense of $\$ 368$ (1) StPO if the taking of evidence is not possible in a legally permissible

92. Cf. Engländer and Zimmermann, above n. 34, § 364b.6; Marxen and Tiemann, above n. 38, n. 462-463. An overview of 'research material and tools of the defence counsel' can be found in Strate, above n. 57, at 233-4. The author - himself a highly experienced defence lawyer, including in retrial procedures - points out that in the light of the lack of coercive powers, the defence is reliant on showing potential interlocutors the meaningfulness of the request for retrial. Moreover, he highlights opportunities for making use of specialist expertise.

93. More details on the effects of appointment under the law on fees, Engländer and Zimmermann, above n. 34.

94. Cf. Engländer and Zimmermann, above n. 34, § 364a.1.

95. A comprehensive overview of the current debate can be found in Arnemann, above n. 3, at 397 et seq

96. In the sense of Engländer and Zimmermann, above n. 34, § 368.14; Eschelbach, above n. 38, § 368.31; Frister, above n. 7, § 368.11; Kaspar, above n. 38, § 368.7; conversely Schmidt, above n. 6, § 368.10. manner, if the evidence is unattainable for the court or if the evidence must be considered wholly unsuitable from the outset. ${ }^{97}$ The latter is the case if it can be asserted, without any consideration for the previous result of the evidence, that the result promised with the evidence offered cannot be attained according to concrete lived experience. ${ }^{98}$ Whilst some of the literature wishes to apply this restrictive standard exclusively, ${ }^{99}$ the prevailing opinion permits a further evaluation of the probative force of the new evidence and - within certain limits an anticipation of the consideration of the evidence in the additional process itself. ${ }^{100}$ Critics see in this a key reason for the low rate of success of petitions for retrial based on $\$ 359$ no. 5 StPO. ${ }^{101}$ According to the prevailing opinion, the principle of in dubio pro reo should also not apply otherwise in this regard since the court does not have to be convinced by the new bringing of facts, but rather simply makes a predictive decision. ${ }^{102}$

A permissible petition shall be presented to the complainant's counterparty - meaning the Public Prosecutor's Office in the case of a petition by a convicted person 'with a time limit being set for a response' ( $\$ 368(2)$ $\mathrm{StPO})$. The preferred interpretation sees in this a rule for granting a legal hearing before the giving of a decision of permissibility (not legally governed in more detail) $;^{103}$ the still prevailing opinion, on the other hand, assumes that $\S 368(2)$ StPO refers to the provision of the decision of permissibility to the counterparty, with the result that only the Public Prosecutor's Office must be heard before the giving of the decision according to $\S 33(2)$ StPO. ${ }^{104}$

\subsubsection{Reviem of the Merit of the Petition for Retrial (Probationsverfahren)}

With the decision to approve the petition, the Additionsverfahren moves on to the so-called Probationsverfahren

97. Engländer and Zimmermann, above n. 34, § 368.14; Frister, above n. 7, $\S 368.11$.

98. Engländer and Zimmermann, above n. 34, § 368.14.

99. Eschelbach, above n. 38, § 368.31; Kaspar, above n. 38, § 368.7 .

100. Cf. BGHSt 17, 303 (304); BGH, Resolution of 22 October $1999-3$ StE 15/93-1 - StB 4/99, NStZ 2000, 218; Engländer and Zimmermann, above n. 34, § 368.31; Schmidt, above n. 6, § 368.10. However, according to the case law of the German Federal Constitutional Court, 'the assertion of such facts which greatly support the verdict of guilty, in that they demarcate the adjudged act in its crucial characteristics, or the confirmation or presentation of which play a predominant role in the defence of the defendant, must in any case be reserved for the main proceedings' (BVerfG, Resolution of the 2nd Chamber of the Second Senate of 7 September 1994 - 2 BvR 2093/93, NJW 1995, 2024 2025).

101. According to Marxen and Tiemann, above n. 38, n. 199, the 'characteristic of suitability [is] of the greatest practical importance. Lack of suitability is in practice the most frequently applied grounds for rejection'.

102. K. Volk and A. Engländer, Grundkurs StPO [A Basic Course in the StPO] (9th edn, 2018), § 38.19; see also BGHSt 39, 75 (85); Schmidt, above n. $6, \S 368.13$; criticism in B. Schünemann, 'Das strafprozessuale Wiederaufnahmeverfahren propter nova und der Grundsatz 'in dubio pro reo" [The Criminal Law Procedure of the Retrial propter nova and the Principle of 'in dubio pro reo'], 84 Zeitschrift für die gesamte Strafrechtswissenschaft 870 , at 889 et seq. (1972).

103. Engländer and Zimmermann, above n. 34, § 368.54; Frister, above n. 7, $\S 368.12$.

104. Kaspar, above n. 38, § 368.13; Schmitt, above n. 6 , § 368.13 
(hearing of the petition), in which a decision is reached regarding the merit of the petition for retrial.

Pursuant to $\$ 369$ (1) StPO, the taking of evidence shall be performed by a judge appointed by the retrial court. This formulation must not be understood in the technical sense; rather, as well as petitioning another judge in the sense of $\$ 156$ et seq. GVG, a taking of evidence by members or the whole of the panel of judges which has jurisdiction according to $\S 140 \mathrm{a}$ GVG shall also be considered. ${ }^{105}$ Conversely, evidence obtained exclusively by the police or the Public Prosecutor's Office is unusable. ${ }^{106}$ According to popular opinion, the principle of the inquisitorial system (Amtsermittlung; § 244(2) StPO) has to be applied accordingly in the Probationsverfahren; the collecting of evidence shall consequently be extended to all facts which are of significance for the retrial $e x$ officio. ${ }^{107}$ By some scholars, however, only a power, not an obligation, to extend the taking of evidence to additional evidence is assumed. ${ }^{108}$ However, the wording of $\$ 369$ (1) StPO, which speaks of the 'taking of the evidence adduced' (our emphasis), and the structure of the retrial process aimed at the principle of party disposition speak in favour of limiting the taking of evidence, in the preferable opposing opinion, to the evidence indicated by the complainant. ${ }^{109}$ However, from the claim to a fair and due process of law, there follows an obligation of the court to exhaustively utilise the evidence indicated by the complainant, and to direct queries to an expert, for example. ${ }^{110}$ If witnesses or experts are questioned, or if the court undertakes a physical inspection, then the Public Prosecutor's Office, the defendant, and counsel have a right to be present $(\$ 369(3)(1)$ StPO).

After the taking of evidence is completed, the defendant and the Public Prosecutor's Office shall be given an opportunity to submit an opinion (\$369(4) StPO). If the claims made in the petition have 'not [been] sufficiently substantiated', then the petition is rejected as unfounded without oral proceedings pursuant to $\S 370(1)$ $\mathrm{StPO}$; the same applies according to this regulation if, in the case of a petition for retrial based on a document offence or the false statement of a witness or expert pursuant to $\S 359$ nos. 1,2 or $\S 362$ nos. 1,2 StPO, "the assumption that the act specified in these provisions

105. Cf. Kaspar, above n. 38, § 369.3; Schmidt, above n. 6, § 369.6.

106. Kaspar, above n. 38, § 369.4; Marxen and Tiemann, above n. 38, n. 366.

107. Higher County Court Zweibrücken, Resolution of 1 February 1993 - 1 Ws 432/92, Goltdammer's Archiv 1993, 463 (465); Higher County Court Hamburg, Resolution of 17 July 2000 - 1 Ws 53/00, Strafverteidiger 2003, 229; Kaspar, above n. 38, § 369.2; Roxin and Schünemann, above n. 5, § 57.15; Schmitt, above n. 6, § 369.5

108. Cf. Schmidt, above n. 6 , § 369.2 .

109. Cf. Engländer and Zimmermann, above n. 34, § 369.9 et seq.; Eschelbach, above n. 38, § 369.2 et seq.; Frister, above n. $7, \S 369.8$ et seq.; Marxen and Tiemann, above n. 38, n. 370.

110. Frister, above n. 7, § 369.8 under reference to BVerfG, Resolution of the 2nd Chamber of the Second Senate of 23 December $2002-2$ BvR 1439/02, Strafverteidiger 2003, 223 (224). As Frister (ibid n. 10) makes clear, the emphasis the prevailing opinion puts on the obligation to pursue the inquisitorial system may be derived from efforts 'to undertake significant parts of a taking of evidence reserved for the main proceedings during the Probationsverfahren itself, and where applicable to assert insufficient confirmation of the bringing of the retrial'. influenced the decision can be ruled out given the circumstances which pertain'. The rejection of the petition as impermissible is subject to immediate appeal ( 372 , clause 1 StPO).

However, when a claim can be assumed to be 'sufficiently substantiated' in the sense of $\S 370(1)$ StPO has been contested in detail. ${ }^{111}$ By some authors, the sufficient likelihood of a more favourable decision for the complainant in the new main proceedings is demanded in this context without further differentiation. ${ }^{112}$ However, the correct approach is to differentiate between the grounds for retrial. ${ }^{113}$ Thus, for those grounds which are associated with criminal behaviour $(\$ 359$, nos. 1-3, $\S 362$, nos. 1-3 StPO), the full conviction of the court that there exists a criminal act is required, insofar as a retrial, by way of exception, is permissible without a legally effective sentence pursuant to $\S 364$, clause 1 (2nd alternative). ${ }^{114}$ For a retrial on the grounds of a believable confession by the acquitted person $(\$ 362$, no. $4 \mathrm{StPO})$, the level of suspicion necessary to initiate the main proceedings pursuant to $\S 203$ StPO is crucial. ${ }^{115}$ With respect to a retrial in favour of the defendant on the grounds of new facts or evidence ( $\$ 359$, no. 5 StPO), the prevailing opinion demands sufficient likelihood of a retrial being brought, ${ }^{116}$ whilst in one minority opinion the mere possibility of correctness should suffice. ${ }^{117}$

If the petition is well-founded, then 'the court shall order the reopening of the proceedings and the recommencement of the main hearing' ( $\$ 370(2)$ StPO). This resolution has far-reaching significance; it nullifies the substantive legal force and enforceability of the first ruling. 118

\subsubsection{Reopening the Main Proceedings}

The new main proceedings to be held on the grounds of a successful petition for retrial are independent of the proceedings, in which the first ruling was made; in these proceedings, 'the set of evidence must be completely rebuilt from scratch'. ${ }^{119}$ The end result - just as in any other main criminal proceedings - may be a sentencing, an acquittal or a suspension of proceedings. However, a prohibition on reformatio in peius applies; i.e.

the original judgment, so far as it relates to the type and degree of the legal consequences of the offence,

111. For an overview of the current debate, cf. Engländer and Zimmermann, above n. 34, § 370.6 et seq.

112. Cf. Schmidt, above n. 6, § 370.4; Volk and Engländer, above n. 102, $\S 38.20$.

113. Cf. Engländer and Zimmermann, above n. 34, § 370.6; Frister, above n. $7, \S 370.4$

114. This relates to cases where 'criminal proceedings cannot be commenced or conducted for reasons other than lack of evidence'. Cf. Engländer and Zimmermann, above n. 34, § 370.8; Frister, above n. 7, § 370.4.

115. Cf. Frister, above n. 7, § 370.5; Schmidt, above n. 6, § 370.4

116. Cf. Engländer and Zimmermann, above n. 34, § 370.10, 14; Schmitt, above n. $6, \S 370.4$

117. Cf. Schünemann, above n. 102, at 898 ; in substance, also Frister, above n. $7, \S 370.13$.

118. Cf. Roxin and Schünemann, above n. 5, § 57.16; in detail, see Engländer and Zimmermann, above n. 34, § 370.19 et seq.

119. Roxin and Schünemann, above n. $5, \S 57.17$. 
may not be amended to the convicted person's detriment if only the defendant or, on his behalf the public prosecution office, or his statutory representative applied to reopen the proceedings. $(\S 373(2)(1)$ StPO)

However, orders to place the defendant in a psychiatric hospital or in an addiction treatment facility may be instructed for the first time $\left(\S 373(2)(2)\right.$ StPO).${ }^{120}$ An acquittal can also be made without reopening the main proceedings if the convicted person dies ( $\$ 371(1)$ StPO), or if there exists sufficient evidence for an acquittal and the Public Prosecutor's Office consents (§ 371(2) StPO).

\subsubsection{Damage Compensation for Wrongfully Prosecuted Persons}

In the event of a successful retrial in favour of the convicted person, he shall in principle have a right to damage compensation for the disadvantages suffered as a result of the sentence according to the German Act on Damage Compensation for the Wrongfully Prosecuted (Strafverfolgungsentschädigungsgesetz; StrEG). ${ }^{121}$ According to $\S 7(3)$ StrEG, compensation for damages which are not pecuniary in nature is just 25 euros per started day of detention. ${ }^{122}$ According to a draft bill approved by the German Bundesrat (Federal Council) in December 2019, this amount should henceforth be set at 75 euros. ${ }^{123}$ It should be noted that compensation pursuant to $\S 5(2)(1)$ StrEG is excluded if and insofar as the accused has caused the criminal prosecution by means of wilful intent or gross negligence'. ${ }^{124}$

\section{Legal Reality of the Retrial Process}

No official statistics are kept regarding successful retrial processes in Germany; the actual number of judicial errors is therefore primarily the subject of more or less well-founded estimates by legal practitioners and jour-

120. This possibility is the consequence of the duality of the German criminal sanctions system. For details, see M. Lindemann, 'Die Zweispurigkeit des deutschen Sanktionensystems - rechtliche Grundlagen und Konsequenzen für die Vollzugsgestaltung' [The Duality of the German Criminal Sanctions System - Legal Basics and Consequences for the Nature of Enforcement], 68 Forum Strafvollzug 99 (2019).

121. See here F. Leuschner and A. Hoffmann, 'Der Umgang des Staates mit Fehlern der Justiz' [The State's Handling of Errors of Justice], 28 Neue Kriminalpolitik 155 (2016).

122. Criticism, see Marxen, above n. 75, at 323.

123. Draft of an ... Act to Amend the Act on Damage Compensation for the Wrongfully Prosecuted (StrEG), BT-Drs. 19/17035. In its meeting of 1 July 2020, the Parliamentary Committee on Legal Affairs and Consumer Protection of the German Bundestag recommended the adoption of the proposal; see BT-Drs. 19/20659.

124. However, the claim to damage compensation is "not excluded by the fact that the defendant has limited himself to a statement on the case only, or by the fact that he has omitted to lodge an appeal' $(\S 5(2)(2)$ StrEG). nalists. ${ }^{125}$ However, alongside the substantial work of $\mathrm{K}$. Peters from the 1970s, there are also a few newer empirical studies devoted to the subject, which are discussed below. ${ }^{126} \mathrm{~A}$ joint interdisciplinary project on the issue of 'Errors and retrials in the criminal process', funded by the German research funding organisation Deutsche Forschungsgemeinschaft, promises significant gains in knowledge, although it is not scheduled to be completed until March 2022. ${ }^{127}$ According to data from the German Federal Office of Statistics (Statistisches Bundesamt), in 2018 a total of 325 proceedings held before district (Amtsgericht) and county courts (Landgericht) were initiated by a petition for a retrial to the disadvantage of the defendant, and a total of 1,000 by a petition for a retrial in favour of the convicted. ${ }^{128}$ However, as already mentioned above, data on the success of these petitions for retrial cannot be obtained from these statistics.

Amongst the studies presented in the recent past with a focus on the right to a retrial, mention must be made of a study carried out at the Kriminologische Zentralstelle (KrimZ) in Wiesbaden, which is based on an in-depth analysis of successful retrial processes. ${ }^{129}$ The study supposedly involved all persons who were wrongfully (as evidenced by a successful retrial) given a prison sentence between 1990 and 2016. Ultimately, the files of 29 proceedings affecting 31 convicted persons were evaluated; the files for a further six proceedings were no

125. Evidence in S. Barton, M. Dubelaar, R. Kölbel \& M. Lindemann (eds.), 'Vom hochgemuten, voreiligen Griff nach der Wahrheit...' Fehlurteile im Strafprozess ['On the Energetic, Rushed Search for the Truth...' Judicial Errors in the Criminal Process] (2018) 9, at 13-14. Estimates of the prevalence of judicial errors range from the low single figures to $10 \%$ or even $25 \%$.

126. K. Peters, Fehlerquellen im Strafprozeß, Bände 1-3 [Sources of Errors in the Criminal Process, vols 1-3] (1970-1974). Regarding larger, mostly older empirical studies, cf. the overview in Arnemann, above n. 3, at 186 et seq. For an overview of the latest research, cf. also B. Dunkel and S. Kemme, 'Fehlurteile in Deutschland: eine Bilanz der empirischen Forschung seit fünf Jahrzehnten' [Judicial Errors in Germany: A Review of Five Decades of Empirical Research], 28 Neue Kriminalpolitik 138 (2016).

127. Involved in the project are Kriminologische Forschungsinstitut Niedersachsen e.V. (Criminological Research Institute of Lower Saxony) (Prof Thomas Bliesener), the Heinrich-Heine University Düsseldorf (Prof Karsten Altenhain) und die Psychologische Hochschule Berlin (Berlin Psychological University) (Prof Renate Volbert). More information can be found on the project homepage; $c f$.https://kfn.de/forschungsprojekte/ fehler-und-wiederaufnahme-im-strafverfahren/ (accessed on 26 July 2020).

128. Statistisches Bundesamt (eds.), Rechtspflege Strafgerichte Fachserie 10 Reihe 2.3 [Administration of Justice in Criminal Courts Special Series 10 Vol 2.3] (2019); accessible online at https://tinyurl.com/y54x5bda (accessed on 26 July 2020). B. Dunkel conducts a time-series analysis on these data in Fehlentscheidungen in der Justiz. Systematische Analyse von Wiederaufnahmeverfahren in Strafverfahren im Hinblick auf Häufigkeit und Risikofaktoren [Wrongful Decisions in the Justice System. A Systematic Analysis of Retrial Procedures in Criminal Proceedings with respect to Frequency and Risk Factors] (2018), at 156 et seq.

129. Some of these results have also been published in English; cf. F. Leuschner, M. Rettenberger \& A. Dessecker, 'Imprisoned But Innocent: Wrongful Convictions and Imprisonments in Germany, 1990-2016', 66 Crime \& Delinquency 687 (2020). More details in A. Hoffmann and F. Leuschner, Rehabilitation und Entschädigung nach Vollstreckung einer Freiheitsstrafe und erfolgreicher Wiederaufnahme [Rehabilitation and Damage Compensation after Imposition of a Prison Sentence and Successful Retrial] (2017) 
longer available. ${ }^{130}$ The overwhelming majority of persons affected had been convicted of sexual offences $(38.7 \%)$ or serious violent offences $(35.5 \%) .{ }^{131}$ The reasons for these judicial errors were predominantly false accusations $(\mathrm{N}=12)$ and incorrect evidence from expert witnesses (12); other frequent reasons were (a failure to recognise) lack of criminal liability (8), misidentification by eye witnesses (5) and false confessions (5). ${ }^{132}$ As part of the overall project, questions surrounding rehabilitation and damage compensation after a successful retrial were also investigated in detail; to do this, 17 interviews were carried out in addition to the file analysis with affected persons and professional actors in the criminal proceedings. ${ }^{133}$ It was shown here that there is still a significant need for improvement in terms of the economic and social reintegration of persons who have previously been wrongfully incarcerated. $^{134}$

B. Dunkel presented an analysis of retrial files based on petitions for retrial submitted to the courts in the Hanseatic City of Hamburg between 2003 and 2015. ${ }^{135}$ As a result, she was able to include 48 files in the investigation; of those, 44 were in favour of the convicted, and 4 to the disadvantage of the defendant. ${ }^{136} 56 \%$ of the retrials related to penalty orders pursuant to $\$ 407$ et seq. StPO. ${ }^{137}$ Since this study, unlike the KrimZ study, did not restrict itself to convicted persons who had been wrongfully given a detention sentence (the proportion of financial penalties was $66.7 \%$ ), the deviation in distribution of types of offence is not surprising: here, theft and robbery $(25.0 \%)$, fraud $(20.8 \%)$ and highway offences (10.4\%) dominated. ${ }^{138} 60.5 \%$ of proceedings before the District Court were successful; before the County Court, this figure was only $22.2 \%{ }^{139}$ The reasons for

130. A comprehensive description of the methodology can be found in Leuschner, Rettenberger \& Dessecker, above n. 129, at 694 et seq.

131. Cf. Leuschner, Rettenberger \& Dessecker, above n. 129, at 697.

132. Ibid., at 701.

133. Cf. Hoffmann and Leuschner, above n. 129, at 34 et seq

134. Ibid., at 58 et seq

135. Cf. Dunkel, above n. 128 , at 169 et seq.

136. On methodology, cf. Dunkel, above n. 128 , at 170 et seq.; on distribution of aims of retrial cf. ibid, at 184.

137. Cf. Dunkel, above n. 128, at 180. On the particularities of the penalty order process, cf. above n. 31. It must be assumed that this process, held in writing, is not particularly well suited to identifying particularities lying in the person of the defendant (such as diminished responsibility in the sense of $\S 20 \mathrm{StGB}$ ), and that many defendants are overwhelmed by the formalities of the criminal process, such that a not insignificant number of penalty orders become legally effective without there having been any real opportunities for defence by means of an objection. For an in-depth analysis of the susceptibility of the penalty order process to error from the Swiss perspective, cf. G. Gilliéron, 'Fallstricke für die Wahrheitsfindung in summarischen Verfahren' [Pitfalls for Establishment of the Truth in Summary Proceedings], in S. Barton, M. Dubelaar, R. Kölbel \& M. Lindemann (eds.), 'Vom hochgemuten, voreiligen Griff nach der Wahrheit..." Fehlurteile im Strafprozess (2018) 59, at 68 et seq.

138. Cf. Dunkel, above n. 128 , at 181

139. Ibid., at 188. According to Dunkel, one explanation for this difference could be that in proceedings before the Country Court which regularly deal with more serious allegations, the preliminary investigation and the taking of evidence in the main hearing are conducted more carefully. Perhaps, however, the decisions of the Country Court are simply met with more trust. the first ruling being wrongful were dominated by failure to observe a psychological condition $(\mathrm{N}=12)$ and a lack of or wrongly collected evidence (8). ${ }^{140}$

As part of her investigation into 'Shortcoming(s) in retrying criminal cases', C. Arnemann conducted guided interviews with 13 specialist criminal defence lawyers. ${ }^{141}$ The results of the work are largely impossible to summarise due to the qualitative approach underlying it; ${ }^{142}$ however, it is nevertheless significant that the prospect for success of retrials is considered by the criminal defence lawyers to be extremely small:

Retrial is not a functioning legal remedy, it's an illusory area of law. It's only successful in extremely exceptional cases. The whole of retrial law is just about blocking. Therefore, most clients have to be advised against a petition for retrial in the opinion of the experts questioned. ${ }^{143}$

The work also contains statements on the regional differences in the frequency of petitions for retrial which are clear from the legal statistics:

Regional differences in how courts handle retrial processes were not reported. The fluctuating number of petitions for retrial between different German Bundesländer can be traced back to the engagement and specialisation of the defence lawyers. For example, more engaged criminal defence lawyers are located in large cities. The criminal defence lawyer located in a rural area lacks the experience, and the opportunity to discuss the case with colleagues, and also access to specialist libraries. ${ }^{144}$

A key problem mentioned is that the courts de facto organised the review of permissibility as a review of merit, meaning that many petitions for retrial failed in the Additionsverfahren itself. ${ }^{145}$

\section{Current Developments in Legal Policy}

In the past, it was above all the principled exclusion of a retrial to the disadvantage of the defendant in the case of the bringing of new facts or evidence (on the limited exception for penalty order proceedings, cf. $\S 373 \mathrm{a}(1)$ StPO) that was repeatedly the subject of political initiatives. ${ }^{146}$ Examples of this include the draft of a bill on reforming the right to a retrial under criminal law introduced by the Bundesrat in 2008 at the initiative of the Bundesländer of Hamburg and Nordrhein-Westfalen.

140. Cf. Dunkel, above n. 128 , at 191

141. Cf. Arnemann, above n. 3, at 216 et seq.

142. On methodology, ibid., at 217 et seq.

143. Cf. Arnemann, above n. 3, at 270-1.

144. Ibid., at 271 .

145. Ibid., at 276. Cf. on this issue also Frister, above n. 7, § 369.10.

146. For an overview of previous legislative initiatives to be recorded, cf. Arnemann, above n. 3, at 172 et seq. 
According to the plans of the draft's authors, a no. 5 was to be added to $\S 362 \mathrm{StPO}$, which would then have also allowed a retrial to the disadvantage of the defendant

if new facts or evidence, which alone or in connection with evidence previously collected are liable to convict the acquitted person, and which were not available at the time of making the ruling, in which the assertions underlying the ruling were last reviewed, are brought on the grounds of new scientifically recognised, technical investigation methods. ${ }^{147}$

What was primarily meant in this regard was technical progress in the area of DNA analysis. ${ }^{148}$ The new opportunity for retrial to be created as a result was to remain limited to acquittals regarding accusations of murder and only homicide crimes potentially subject to a sentence of life imprisonment according to the German Code of Crimes against International Law (Völkerstrafgesetzbuch; VStGB), ${ }^{149}$ as well as incitement to such crimes which are punished with life imprisonment. ${ }^{150}$ Following a hearing of experts before the German Parliamentary Committee of Legal Affairs (Rechtsausschuss), the proposal was abandoned on the grounds of constitutional reservations. ${ }^{151}$ A draft largely identical in content, which can be traced back to Nordrhein-Westfalen, from $2010^{152}$ was also unsuccessful.

This notwithstanding, the Coalition Agreement of the German Grand Coalition for the current legislative period contains the following declaration of intent: 'We shall expand the opportunities for retrial to the disadvantage of the acquitted defendant with respect to criminal acts with no statute of limitations' ${ }^{153}$ The considerable media attention which certain spectacular judicial errors have gained in the recent past ${ }^{154}$ may have contributed to a broad majority of German citizens being not opposed to a corresponding expansion of

147. BT-Drs. 16/7957, at 5

148. Cf. Ibid., at 1: 'Countless examples from previous years show that even in the case of capital offences that have not yet been resolved, it is still possible to convict the perpetrator several years later. DNA analysis in particular delivers scientifically objective results which allow one to prove the act unambiguously'. Criticism here in K. Marxen and F. Tiemann, 'Aus Wissenschaft und Praxis: Die geplante Reform der Wiederaufnahme zuungunsten des Angeklagten' [From Theory and Practice: The Planned Reform to the Retrial to the Disadvantage of the Defendant], Zeitschrift für Internationale Strafrechtsdogmatik 188, at 191 (4/2008).

149. According to this, one could consider genocide ( $\S 6$ VStGB), and in certain cases crimes against humanity ( $\$ 7$ VStGB) and war crimes against persons (§ 8 VStGB).

150. Ibid

151. Cf. here S. Pabst, 'Wider die Erweiterung der Wiederaufnahme zuungunsten des Angeklagten. Eine zu Recht unterbliebene Reform' [Against the Extension of the Retrial to the Disadvantage of the Defendant. A Rightfully Unfulfilled Reform], Zeitschrift für Internationale Strafrechtsdogmatik 126 (2/2010).

152. BR-Drs. 222/10.

153. Ein neuer Aufbruch für Europa. Eine neue Dynamik für Deutschland. Ein neuer Zusammenhalt für unser Land. Koalitionsvertrag zwischen CDU, CSU und SPD. [A New Start for Europe. A New Dynamic for Germany. A New Cohesion for Our Country. Coalition Agreement between CDU, CSU and SPD] 19th Legislative Period, n. 5853-5854 (accessible online at https://tinyurl.com/y66cv3on (accessed on 26 July 2020).

154. Cf. here Velten, above n. 2, at 387 opportunities for retrial to the disadvantage of the defendant. ${ }^{155}$ While the Federal Minister of Justice and Consumer Protection is showing a certain reluctance to implement the project, ${ }^{156}$ the Ministers of Justice of the German states have asked her at their autumn conference on 26 November 2020 to present a draft bill to extend the provisions of the Code of Criminal Procedure regarding the retrial to the disadvantage of the defendant 'to include cases of the most serious crimes where new scientific investigation methods make it predominantly probable that the perpetrator is subsequently proven guilty'. ${ }^{157}$

It is to be hoped that this initiative will ultimately remain unsuccessful, as the project is being met with fundamental constitutional concerns. In fact, the suggestion of creating a general opportunity for retrial to the disadvantage of the defendant on the grounds of new facts is rightly being contested: In contrast to the narrowly restricted grounds for retrial ${ }^{158}$ already standardised in basic law under $\$ 362$ nos. 1-4 StPO, this would undermine the essence of the principle of ne bis in idem which is granted a constitutional rank in $\$ 103(3)$ GG and which has been declared sacrosanct ${ }^{159}$ by the Federal Constitutional Court. ${ }^{160}$ The sword of Damocles, in the form of new facts or evidence which indicate perpetration by the defendant with a degree of likelihood satisfying the requirements of the grounds for retrial, would always hang over any acquittal. Insofar as a restriction to new knowledge from DNA analysis which was not yet available at the time of the acquittals has been suggested, it has been correctly pointed out that the proposed revision would not be capable of solving the problem due to the general principle of non-retroactivity. ${ }^{161}$ Moreover, the advance in criminal knowledge as such, evoked in the reasoning of the failed drafts

155. Frister and Müller, above n. 7, at 101 citing a representative survey, according to which approximately $91 \%$ of German citizens would welcome the extension being discussed.

156. 'Mordprozesse trotz Freispruch wiederaufnehmen? Regierung prüft' [Reopening Murder Trials Despite Acquittal?], Report from the Neue Osnabrücker Zeitung of 9 July 2020; accessible online at https:// tinyurl.com/y4340w49 (accessed on 26 July 2020).

157. Decision of the Conference of Ministers of Justice on TOP II 1: Changes in procedural law for long-standing serious crimes; accessible online at https://tinyurl.com/y53c78un (accessed on 7 December 2020).

158. On the compatibility of this with the Grundgesetz, cf. Frister, above n. $7, \S 362.3$ with citations.

159. Cf. BVerfGE 56, 22 (34-35).

160. In agreement, for example, Frister and Müller, above n. 7, at 103; ultimately also A. Bohn, Die Wiederaufnahme des Strafverfahrens zuungunsten des Angeklagten vor dem Hintergrund neuer Beweise [The Retrying of Criminal Proceedings to the Disadvantage of the Defendant in light of New Evidence] (2016), at 237; Greco, above n. 5, at 978-9; generally also Engländer and Zimmermann, above n. 34, above $\S 359.43$ ('extremely dubious proposal under constitutional law'); Wissenschaftliche Dienste des Bundestages, Report WD 7 - 3000 - 121/16, at 12 ('weighted arguments against an ... extension'). Conversely, for compatibility of a corresponding proposal with the Grundgesetz cf. Kaspar, above n. 38, § 362.14-15; C. Zehetgruber, 'Ist eine Erweiterung der Wiederaufnahmegründe zu Ungunsten des Angeklagten möglich?' [Is an Extension of the Grounds for Retrial to the Disadvantage of the Defendant Possible?], Juristische Rundschau 157, at 166 (2020).

161. Cf. Frister and Müller, above n. 7, at 103 under reference to Pabst, above n. 151, at 130 . 
of 2008 and 2010, is not in itself a new development; rather it has its roots back in the 19th century and has thus certainly been taken into account by the original legislator. ${ }^{162}$ Furthermore, it is rightly pointed out that even a positive DNA analysis result in and of itself is not evidence of the guilt of the defendant, but is rather evidence that he had contact with the trace carrier. ${ }^{163}$ Ultimately, the restriction to certain, particularly serious offences stipulated in the failed drafts is also questionable since one may doubt that such a restriction would last long if, for example, serious suspicions would be raised regarding acquittals in grave cases of child abuse or series of violent robberies. ${ }^{164}$ It should be remembered that the last undermining of the principle of ne bis in idem occurred during the time of National Socialism ${ }^{165}$ and that $\S 103(3)$ was added to the Grundgesetz specifically in the light of these experiences. ${ }^{166}$ It is hoped that the German government will reflect on these historical connections and distance itself from the proposal.

\section{Conclusion}

In conclusion, it is clear that one of the most urgent desiderata with respect to the law and practice of the retrial process in Germany is the attainment of up-todate and meaningful empirical knowledge. However, there is cause for hope that the joint interdisciplinary project mentioned above (Section 4) will make a significant contribution to filling existing gaps in knowledge. Moreover, lesser reform issues have been formulated as part of the analysis of the existing legal framework, for example, the requirements to expand the scope of application of $\S 359$ no. $3 \mathrm{StPO}$ to any form of conscious violation of public duty ${ }^{167}$ and to extend $\S 359$ no. $6 \mathrm{StPO}$ to sentences which are based on a legal norm or legal opinion declared to be in contravention of the Convention in another case. ${ }^{168}$ However, the wish for the retrial in favour of the defendant to finally develop into the effective quality assurance mechanism which the historical legislator had in mind ${ }^{169}$ and the functionality of which lies not least of all in the interest of the general

162. Cf. Frister and Müller, above n. 7, at 103 under reference to the dactyloscopy first developed in the 19th century; also Marxen and Tiemann, above n. 148, at 191.

163. Cf. Frister and Müller, above n. 7, at 103.

164. On the questionability of the criterion of offence, $c f$. the Report of the Wissenschaftliche Dienste des Bundestages, above n. 160, at 14; and Marxen and Tiemann, above n. 148, at 193.

165. Details on this Bayer, above n. 3, at 113 et seq.

166. Cf. H. Schulze-Fielitz, in H. Dreier (ed.), Grundgesetz-Kommentar [Grundgesetz Commentary] (3rd edn, 2018), § 103(3) GG n. 5.

167. Above under fn. 49.

168. Above under fn. 75 .

169. Cf. here Marxen, above n. 75 , at 325-4, who points out that historically the fact that rulings of County Courts (Landgerichte), which are regularly based on serious accusations, other than rulings of District Courts (Amtsgerichte) are not subject to an appeal on points of fact and law (Berufung, § 312 et seq. StPO), was justified by the possibility of a retrial. See here also Eschelbach, Geipel, Hettinger, Meller \& Wille, above n. 87 , at $240-41$ public can ultimately be fulfilled by the judiciary alone through a more generous interpretation of $\$ 359$ et seq. StPO bound to the basic legal concept of the right to retrial. ${ }^{170}$ 